\title{
ANALYSIS OF THE DOCTOR-PATIENT COMMUNICATION IF BREAST CANCER IS DIAGNOSED
}

\begin{abstract}
Anna Pacian ${ }^{1}$, Teresa Bernadetta Kulik ${ }^{1}$, Jolanta Pacian ${ }^{1}$, Mariusz Goniewicz², Agnieszka J. Kowalska ${ }^{3}$
Abstract: The aim of the paper is the recognition and evaluation of demand for medical information among patients suffering from breast cancer. The research was conducted among 120 women with diagnosed breast cancer in the Oncological Surgery Clinic of the Independent Public Research Hospital No 1 in Lublin, the Oncological Clinic of the Independent Public Research Hospital No 1 in Lublin and the Rehabilitation Centre with the Rehabilitation Clinic at the Lublin Oncology Centre. The research included women from the Club of Women after Mastectomy "Amazons", the Club "Amazons" at the Complex of Specialist Clinics in Ostrowiec Świętokrzyski and the Club "Amazons" in Radom. Research showed that the demand for medical information among women with diagnosed breast cancer is very high. Respondents want to know all the information concerning the diagnosis, treatment and prognosis (93\%). They also expect that the doctor will give them medical information concerning further consequences of cancer and its influence on future health and life $(78 \%)$. Most of the respondents expect to receive information concerning medicaments which should be taken $(77 \%)$ and the essence of the conducted treatment $(93 \%)$. The research analysis showed that women with diagnosed breast cancer expect that the doctor will give them reliable and real medical information. Patients want the doctor to present them the probable course of the cancer (85\%) and all the possible side effects connected with it (89\%).
\end{abstract}

Key words: doctor, patient communication, right to medical information, unfavourable diagnosis, breast cancer

\section{Análisis de la comunicación médico-paciente en el diagnóstico de cáncer de mama}

Resumen: El objetivo de este trabajo es el reconocimiento y la evaluación de la demanda de información médica en pacientes con cáncer de mama. Se realizó la investigación con 120 mujeres diagnosticadas con cáncer de mama en la Clínica de Cirugía Oncológica y la Clínica Oncológica del Hospital de Investigación Público Independiente No 1 en Lublin, y el Centro de Rehabilitación con la Clínica de Rehabilitación del Centro Oncológico de Lublin. La investigación incluyó mujeres del Club "Amazons” de Mujeres que han sufrido Mastectomía, el Club "Amazons" del Complejo de Clínicas Especializadas en Ostrowiec Świętokrzyski y el Club "Amazons" en Radom. La investigación mostró que la demanda de información médica de mujeres con diagnóstico de cáncer de mama es muy alta. Aquellas que respondieron quieren saber todo acerca del diagnóstico, tratamiento y pronóstico (93\%). También esperan que el médico les dé información médica respecto de posteriores consecuencias del cáncer y su influencia en su salud futura y su vida (78\%). La mayoría de las que respondieron esperan recibir información sobre medicamentos que deberían tomar (77\%) y lo esencial sobre el tratamiento realizado (93\%). El análisis de la investigación muestra que las mujeres diagnosticadas con cáncer de mama esperan que el médico les dé información médica confiable y verdadera, les presente el curso probable del cáncer (85\%) y todos los posibles efectos secundarios conectados (89\%).

Palabras clave: médico, comunicación con el paciente, derecho a información médica, diagnóstico desfavorable, cáncer de mama

\section{Análise da comunicação médico-paciente em caso de diagnóstico de câncer de mama}

Resumo: O objetivo deste artigo é o reconhecimento e a avaliação da demanda por informação médica entre pacientes que sofrem de câncer de mama. A investigação foi conduzida entre 120 mulheres diagnosticadas com câncer de mama na Oncological Surgery Clinic of the Independent Public Research Hospital No 1 de Lublin, a Oncological Clinic of the Independent Public Research Hospital No 1 de Lublin e a Rehabilitation Centre with the Rehabilitation Clinic do Lublin Oncology Centre. A pesquisa incluiu mulheres do Club of Women after Mastectomy "Amazons", o Club "Amazons" do Complex of Specialist Clinics em Ostrowiec Świętokrzyski e o Club "Amazons" em Radom. Pesquisa revelou que a demanda por informação médica entre mulheres com diagnóstico de câncer mamário é muito alta. As respondentes queriam saber todas as informaçôes concernentes ao diagnóstico, tratamento e prognóstico (93\%). Elas também esperavam que o médico pudesse dar-lhes informação sobre consequências tardias do câncer e a influência sobre a sua saúde e vida futuras $(78 \%)$. A maioria dos respondentes tinham a expectativa de receber informaçáa sobre medicamentos que deveriam tomar (77\%) e a essência do tratamento realizado (93\%). A análise da pesquisa demonstrou que as mulheres com diagnóstico de câncer de mama esperavam que o médico pudesse fornecer-lhes informaçáo confiável e honesta. Pacientes queriam que o médico lhes apresentasse o provável curso do câncer (85\%) e todos os possíveis efeitos relacionados a ele (89\%).

Palavras-chave: médico, comunicação com paciente, direito à informação médica, diagnóstico desfavorável, câncer de mama

\footnotetext{
${ }^{1}$ Chair of Public Health, Medical University in Lublin, Poland

Correspondence: apacian@gmail.com

${ }^{2}$ Emergency Medicine Unit, Medical University in Lublin, Poland

${ }^{3}$ Department of IT and Epidemiological Methods, Medical University in Lublin, Poland
} 


\section{Introduction}

The exchange of information is one of the basic conditions for the proper functioning of a unit in a society. Efficient communication among people plays an essential role in humans'lives because it is a crucial element of cooperation and coexistence.

Proper doctor-patient communication is a basic element of a normal diagnosis, therapy and rehabilitation process. Giving the patient medical information is his/her subjective right to truth. One may not talk about freedom in relation to a unit which is deprived of the right to information. Depriving a patient of the right to information on his/her health condition, information on possible and used methods of diagnosis and treatment may be an area for abuse. The rule is that a patient has the right to real and reliable medical information before he/she makes a decision in relation to his/her health or life. The two following arguments are mentioned in relation to an axiological justification of this right: the first points out that because of respect for the patient, it is crucial that he/she knows the truth about his/her health condition; the second, however, presumes that full information on the patient's health condition is a vital condition of the relationship between medical staff and patient. Medical information should be given to the patient an appropriate length of time before the operation so that he/she can think his/her decision over before he/she agrees to concrete medical treatment. An aspect of the need for full information is created by people's fundamental right to autonomy and respect(1-3).

In 1960, the Scottish Association for Mental Health presented research concerning problems of a psychological nature existing among patients treated in hospitals. Research showed that a major cause of the poor physical and mental state of patients, their depression and lowered spirits, was mainly the lack of knowledge and information on the disease, the used and possible treatment, the diagnosis of the disease, time needed to get better and the time when they would fully recover and could start working professionally(4). It is inadvisable to compound fear related to a lack of information. Even the most difficult and unfavourable medical information may be given gradually by the doctor and in a responsible way, with the provision of proper respect for the patient. Such events may play the role of a stimulus motivating the patient to fight the disease. It seems to be essential to turn one's attention to the underestimated role of giving the patient medical information, as well as to the influence of communication between the medical staff and the patient, both of which influence the treatment and recovery pro$\operatorname{cess}(5-8)$.

The Aim of the Paper is the recognition and evaluation of the demand for medical information among patients suffering from breast cancer.

\section{Material and Methodology}

Research with the use of a questionnaire was conducted among patients of the Oncological Surgery Clinic of Independent Public Research Hospital No 1 in Lublin, the Oncological Clinic of Independent Public Research Hospital No 1 in Lublin and the Rehabilitation Centre with the Rehabilitation Clinic at the Lublin Oncology Centre. The research included women from the "Amazons" Lublin Club of Women after Mastectomy, the "Amazons" Club at the Complex of Specialist Clinics in Ostrowiec Świętokrzyski and the "Amazons" Club in Radom.

The research method was a diagnostic survey, the research technique was the author's questionnaire and the standardised questionnaire of the Patient's List of Expectations - PRF - created by Peter Salmon and John Quine and adapted by Z. Juczyński. Research tools used included questions concerning the demand of breast cancer patients for medical information. At the end of each questionnaire, there was a survey which included questions relating to the life and professional situation of the respondents.

In the statistical analysis, a verification of statistical hypothesis based on the $\chi^{2}$ test for independence was presented. The relevance of differences among the research results was stated at the level of $\mathrm{p} \leq 0.05$. Study of the results was done with the use of the STATISTICA(9) programme.

\section{Results}

The research lasted from December 2008 until May 2009, and 120 women with diagnosed breast cancer took part in it. After having analysed 
the results of the research, the group of respondents was divided into three age brackets. The first group are women in the age bracket between 25 49 years (16\%). The second group are women in the age bracket between $50-60$ years (46\%). The last group are women in the age bracket between 61-81 years (38\%). Another essential element describing the group researched is education. 3\% of the respondents had only primary education, $14 \%$ had vocational secondary education, $47 \%$ had secondary education, $8 \%$ of the respondents had post-secondary education, 3\% had higher BA studies and $25 \%$ of the overall number of those researched declared that they had higher education. The marital status of the women researched is as follows: $7 \%$ of the respondents are single women, $71 \%$ are married, $4 \%$ divorced and $18 \%$ are widows. The majority of the respondents live in the city $(82.5 \%)$. Only $17.5 \%$ live in rural areas. To determine the duration of the cancer, five time brackets were introduced: the first time bracket up to 6 months included $31 \%$ of the respondents, the second one from 7 to 12 months included $5 \%$ of the researched people, the third from 1 to 3 years $-13 \%$ of respondents, the fourth one from 3 to 5 years $-13 \%$ and in the last bracket, more than 5 years $-38 \%$. In the case of $76 \%$ of respondents, radical treatment relating to whole breast removal, including the removal of lymph nodes of the axillae, was conducted. Among 14\% of women, an operation which did not include the removal of a piece of the breast with the tumour and lymph nodes of the axillae was conducted. In 5\% of the women, an operation relating to the removal of the tumour and leaving the lymph nodes of the axillae was conducted. $5 \%$ of the respondents were pre-operation during the research.

Reliable medical information should be given to the patient at every stage of the diagnosis, treatment and rehabilitation process out of respect for the patient's autonomy and rights.

An absolute majority of respondents (93\%) claim that a patient should be informed about his/her health condition and the prognosis. Only $3 \%$ of the researched women had a different opinion and the other $4 \%$ did not give a clear answer.
Research shows that an absolute majority of the respondents $(91 \%)$ want to know the results of a diagnostic examination. $6 \%$ of the respondents have, however, a different opinion, and the remaining 3\% are uncertain if they expect the doctor to give them information concerning the results of the examination.

Statistical analysis did not show any dependence between the respondents' location and their expectations relating to information on the results of the conducted examination $(\mathrm{p}=0.620970)$. There is also no dependence between the current professional status and the analysed feature $(p=0.271091)$. No relation was noticed between the age of the respondents and their expectations concerning information about the results of the conducted diagnostic examination ( $\mathrm{p}=0.191946)$. However, a dependence between the analysed feature and the marital status of the respondents was noticed ( $p=0.045722) .100 \%$ of single women expect the doctor to give them information concerning the results of the conducted examination and married women interested in such information is at $93 \%$. The percentage of divorced women and widows expecting to get information concerning the results of the examination is at $80 \%$ and $82 \%$ respectively. $18 \%$ of widows, however, do not want to know the results (tab. 1).

\begin{tabular}{|l|r|r|r|r|r|r|r|r|}
\hline $\begin{array}{c}\text { I want to know } \\
\text { the results of } \\
\text { the exami- } \\
\text { nation }\end{array}$ & \multicolumn{2}{|c|}{ Yes } & \multicolumn{2}{|c|}{ No } & \multicolumn{2}{l|}{ I am not sure } & \multicolumn{2}{c|}{ All togehter } \\
\hline Marital status & $\mathrm{N}$ & $\%$ & $\mathrm{~N}$ & $\%$ & $\mathrm{~N}$ & $\%$ & $\mathrm{~N}$ & $\%$ \\
\hline maiden & 8 & 100 & 0 & 0 & 0 & 0 & 8 & 100 \\
\hline married & 79 & 92.94 & 3 & 3.53 & 3 & 3.53 & 85 & 100 \\
\hline divorced & 4 & 80 & 0 & 0.00 & 1 & 20 & 5 & 100 \\
\hline widow & 18 & 81.82 & 4 & 18.18 & 0 & 0 & 22 & 100 \\
\hline All togehter & 109 & 90.83 & 7 & 5.83 & 4 & 3.33 & 120 & 100 \\
\hline
\end{tabular}

Chi^2 Pearsona: $12,8362, \mathrm{df}=6, \mathrm{p}=0,045722$

Tab. 1 Dependence between the marital status of the respondents and their expectations concerning information related to the conducted examination.

Among the overall number of women who took part in the research $(\mathrm{N}=120)$, more than $92 \%$ expect that the doctor will discuss the results of the diagnostic examination and $6 \%$ have a different opinion. Less than $2 \%$ of the respondents are 
uncertain if they expect the doctor to discuss the results of the examination.

The conducted research shows that the majority of the respondents $(85 \%)$ expect the doctor to present a probable course of the disease, $7.5 \%$ of the respondents do not want to know further consequences of the cancer and the same number of women are uncertain if they want to know the future consequences of the cancer.

Among the women who took part in the research, more than $78 \%$ wanted to know whether, in relation to cancer, they may have further health problems in the future. $12 \%$ of the respondents are not interested in such information while $10 \%$ of the respondents are not able to answer this question clearly.

Among the women who took part in the research, an absolute majority of respondents (89\%) want to know the probable side effects of the cancer, more than $77 \%$ expect to receive information on the medication which they ingest and 93\% expect the doctor will explain the basics of the treatment. Statistical analysis did not show any dependence between the expectations of respondents concerning information relating to the ingested medication and their age $(\mathrm{p}=0.572934)$. There is also no dependence between the analysed feature and the education of respondents $(\mathrm{p}=0.932967)$ or the location of the women who took part in the research $(\mathrm{p}=0.096199)$.

Results of the research show that $62 \%$ of the respondents were satisfied with the reliability of information concerning the side effects of the medication used. Only $48 \%$ of the respondents claim that information concerning the diagnosis, treatment and prognosis given by the medical staff was exhaustive and clear.

\section{Discussion on the Research Results}

In the conducted research, attention was given to various aspects of communication between the doctor and the patient in the diagnosis and treatment process. Focus was put on the patient as a subject of bilateral relation to the doctor. The aim of the conducted research was to examine the level of demand for medical information among women with diagnosed breast cancer.

On the basis of the conducted survey, the demand for medical information is very high. According to K. Czubalski, A. Zachara and M. ŁempickaJastrzębska, interest in gaining information on one's own health is shown by $75 \%$ of respondents, and among patients who have cancer this rate is higher, amounting to $91 \%$. Analysis of the research results presented in this paper confirms the results gathered by other scientists. Among women with diagnosed breast cancer, $93 \%$ of respondents claim that a patient should know the diagnosis. Results presented in this paper also showed a dependence between expectations relating to information concerning the diagnostic examinations and the marital status of the respondents $(\mathrm{p}=0.045722) .100 \%$ of single women and $93 \%$ of married women expect the doctor to give them information on the results of the examination. Divorced women and widows expect to get information concerning the result of the examination in percentages of $80 \%$ and $82 \%$, respectively. $18 \%$ of widows, however, do not want to know the results.

Research shows that patients are interested in information on the basics of the conducted treatment. In the presented paper and in papers by K. Czubalski, A. Zachara and M. ŁempickiaJastrzębska, demand for information concerning the treatment process is high, as $90 \%$ of the respondents have shown it. Statistical analysis did not show any dependence between the expectations of respondents concerning information relating to the ingested medication and their age $(p=0.572934)$. There is also no dependence between the analysed feature and the education of respondents $(\mathrm{p}=0.932967)$ and the location of the women who took part in the research $(\mathrm{p}=0.096199)$.

Research presented in this paper and research conducted by other authors (K. Czubalski, A. Zachara i M. Łempicka-Jastrzębska) showed that patients want to know the probable course of cancer and its results. Demand for information on this subject was indicated by almost $90 \%$ of the respondents(10). 
Research conducted in 2007 by the CMJ PASAT in the Independent Public Voivodeship Hospital in Zamość $(\mathrm{N}=784)$ shows that respondents negatively evaluate the information gained concerning the side effects of the medication used. Only $33 \%$ of the respondents claim that the information received from the doctor is not sufficient and is not comprehensible. According to research presented in this paper among women with diagnosed breast cancer, the rate of women who were satisfied with the reliability of the received information concerning side effects is almost twice as high (62\%).

A survey conducted by CBOS in 2001 among people who were treated in the period from the beginning of 1999 until May 2001 ( N=794) showed that medical information given by the doctor concerning the diagnosis, treatment and prognosis were sufficient and comprehensible for $69 \%$ (always in a comprehensible way) and for $37 \%$ (usually in a comprehensible way), whereas research presented in this paper show that this rate is lower at only $48 \%(11)$. The Omnibus research conducted for the first time between April 19-23, 1996, among a group of 1188 randomly chosen adult Polish citizens showed that $64 \%$ of respondents were always informed about their health condition and $21 \%$ almost always received medical information from the doctor(12). Research (with a standardised survey including closed questions concerning regularities in using the right to information) was conducted eight years later by I. Bernatek-Zaguła among 200 patients being treated in a health clinic, dentist's office, in the Voivodeship Hospital in Legnica (also in the Palliative Care Ward), two wards of Wroclaw clinics and among 50 doctors (family doctors, doctors of Wroclaw research hospitals) showed that every tenth patient does not understand at all medical information given by the doctor. Every third respondent sometimes understands everything little. This is caused by the way the doctor gives the information concerning the health condition, proposed treatment and prognosis of the disease. The author's research show that only $28 \%$ of respondents declare that medical information given by the doctor was always fully comprehensible to them, $32 \%$ of patients understood always only some pieces of medical information and $25 \%$ of the sick said: "I sometimes understood everything and sometimes not depending on the doctor who was giving the information". It is worth mentioning that research conducted by I. Bernatek-Zaguła showed that $10 \%$ of the respondents do not understand the medical information given by the doctor and 5\% of them claimed that they have never received any medical information from the doctor. Doctors who took part in this research in majority $(80 \%)$ claimed that medical information given to patients was always clear and comprehensible. Only $10 \%$ of the doctors researched said that information was not so comprehensible because of specialist terminology and the same amount of doctors claimed that the situation depends mainly on the patient. None of the doctors said that he/she does not give medical information to patients at all(2).

The presented results of the research show that there is an essential need to take into consideration more fully than previously the aspect of respecting patients' rights to medical information and improving the quality of the doctor-patient communication.

The way of giving medical information to patients, as well as its reliability and range, play an essential role in the doctor-patient relationship. The personal relationship between the medical staff and the patient, especially a patient who is suffering, has great influence on the new situation and on accepting the disease(13).

Obtained results confirm it that a demand is appearing among patients with cancer of the breast for medical information concerning the diagnosis, prognosis and the process of curing. It results from examinations that the majority of patients doesn't know the accurate diagnosis, prognosis and frequently the course of treatment. In the medical practice, the staff unwillingly undertakes passing the truth about the diagnosis on to the sick person, prognosis particularly when the future seems unfavorable. The reason for it is often anxiety of the reaction of the patient and his/her helplessness in such a situation, as well as lacking a psychological good training in communicating with the incurably ill patient. Providing unfavorable information is a certain kind of a skill, which medical staff in the palliative care should present. 
The role of communication in the palliative care often brings itself to reducing sense of uncertainty through showing the concern, the kindliness and the patience, pointing and supporting of hope, than hope for total getting well, concerning the transmission of information about the illness, prognosis, curing as well as supporting the patient and his family in the situation of surviving strong emotions such as fear, despair, anger or depression. Providing disadvantageous information is an ability which above all a doctor should be familiar with since he/she is competent most in the transmission of information.

Obtained findings are of certain kind of a message for the need of paying attention to the undergraduate and postgraduate education of future medical staff in the interpersonal communication with the patient ill from cancer. Focusing in the process of training on passing unfavorable information to a patient with cancer would allow communicating the truth which is necessary to be administered depending on individual needs and sensitivity of the sick person.

\section{Conclusions}

1. Demand for medical information is very high among patients with diagnosed breast cancer. An absolute majority of respondents (93\%) claim that a patient should be informed about his/her health condition and the prognosis of the disease. Respondents want to know the results of the conducted diagnostic examination $(91 \%)$ and expect that the doctor will discuss them $(92 \%)$.
2. From the conducted survey, one may conclude that $85 \%$ of the respondents expect that the doctor will present them with the probable course of the disease. The majority of respondents $(78 \%)$ want to know if, in relation to cancer, they may encounter other health problems in the future and $89 \%$ of women with diagnosed breast cancer want to know the possible side effects of said cancer.

3. Interest in information concerning the conducted treatment among women with diagnosed breast cancer is very high. The research presented in this paper shows that over $77 \%$ of respondents expect to receive information on the medication which they ingest and $93 \%$ expect the doctor will explain the basics of the treatment.

4. Results of the research show that $62 \%$ of the respondents were satisfied with the reliability of information concerning the side effects of medication used. It is, however, alarming that just less than half of the respondents $(48 \%)$ claim that information given by the medical staff was exhaustive and clear. One must stress that research of other authors shows that doctor-patient communication does not fully satisfy all the informational needs of patients. 


\section{References}

1. Hebanowski M, Kliszcz J, Trzeciak B. Poradnik komunikowania sięlekarza z pacjentem (Guide on How a Doctor Should Communicate with a Patient). Warsaw: Wyd. Lek. PZWL; 1994: 47.

2. Bernatek-Zaguła I. Prawo pacjenta w Polsce do informacji medycznej (Patient's Right to Medical Information in Poland). Toruń; 2008: 6-190.

3. Nesterowicz M. Prawo pacjenta i zadośćuczynienie pieniężne za ich naruszenie (Patient’s Right and Financial Compensation for its Violation), Prawo i Medycyna 2005; 2: 88.

4. Świrydowicz T. Psychologiczne aspekty przekazywania niepomyślnych informacji o rozpoznaniu choroby i prognozie. (Psychological Aspects of Giving Unfavourable Information about the Diagnosis of the Disease and the Prognosis). Nowa Medycyna 2000; 1: 74 .

5. Tobiasz-Adamczyk B, Bajka J, Marmon G. Wybrane elementy socjologii zawodów medycznych (Chosen Elements of the Medical Profession Sociology), Kraków: Collegium Medicum UJ; 1996.

6. Barański J. Interakcja lekarz-pacjent (Doctor-Patient Interaction). In: Barański J, Piątkowski W. (ed.) Zdrowie i choroba Wybrane problemy socjologii medycyny (Health and Disease. Chosen Problems of the Medicine Sociology). Wrocławskie Wydawnictwo Oświatowe: Oficyna Wydawnicza Atut; 2002: 158-161.

7. Gordon T, Edwards WS. Pacjent jako partner (Patient as a Partner). Warszawa: Instytut Wydawniczy Pax; $1999: 37$.

8. Czerska B. Orientacja na wartości w praktyce onkologa. Wierność, Onkol. Prakt. Klin. 2006; 2(3): 95-98.

9. Watała C. Biostatystyka-wykorzystaniem metod statystycznych w pracy badawczej $w$ naukach biomedycznych (Biostatistics as a Use of Statistical Methods in Research and in Biomedical Science). Bielsko Biała: Wydawnictwo a-Medica Press; 2002: 121-130.

10. Czubalski K, Zachara A, Łempicka-Jastrzębska M. Wyniki wstępnych badań postaw, opinii i zachowań lekarzy dotyczących informowania chorych na nowotwory złośliwe o ich rozpoznaniu (Results of Preliminary Research of Attitudes, Opinions and Behaviour of Doctors Relating to Giving Information to Patients who Have Malignant Cancer), Nowotwory 1992: 42: 261-268.

11. Centrum Badania Opinii Spotecznej. www.cbos.pl

12. Łamanie praw pacjentów, Komunikat z badań (Violation of Patients' Rights, Research Announcement). Zdrowie Publiczne 1997; VII, Supplement II: 23-35.

13. Ślusarska T., Stosunki społeczne w środowisku pacjentów szpitalnych (Social Relations in the Hospital Environment of Patients). Szpitalnictwo Polskie 1982; 26(3): 79.

Received: November 27, 2011

Accepted: June 13, 2012 